\title{
Stabilisasi Tablet Yang Mengandung Zat Aktif Bersifat Higroskopis
}

Fitri Nurjanah$^{1}$, Sriwidodo ${ }^{1}$ Bambang Nurhadi

1Departemen Farmasetika dan Teknologi Farmasi, Fakultas Farmasi, Universitas Padjadjaran,, Jatinangor 453632

2Departemen Teknologi Industri Pangan Fakultas Teknologi Industri Pertanian, Universitas Padjajaran, Jatinangor 45363

*e-mail: fitri16004@mail.unpad.ac.id

(Submit 16/5/2020, Revisi 21/5/2020, Diterima 03/08/2020)

\section{Abstrak}

Rute pemberian obat secara oral banyak disukai masyarakat karena mudah digunakan. Salah satu bentuk sediaan oral yang paling disukai adalah tablet. Tablet adalah bentuk sediaan padat yang mengandung bahan aktif dengan atau tanpa eksipien. Dalam formulasi tablet, kandungan air zat aktif dan eksipien padat merupakan parameter penting yang harus dipantau selama proses pengembangan produk obat. Pada sediaan padat, senyawa yang bersifat higroskopis dapat menimbulkan masalah yang dapat mempengaruhi aliran serbuk, kompresibilitas, dan kekerasan tablet. Pada review artikel ini akan dibahas mengenai pengaruh kelembapan terhadap karakteristik fisika tablet dan upaya menjaga stabilitas zat aktif yang sensitif terhadap kelembapan. Review ini menyimpulkan bahwa pemilihan eksipien, penyalutan tablet dan kemasan yang tepat dapat menjaga kestabilan tablet dari pengaruh kelembapan.

Kata kunci: Tablet, zat aktif, stabilisasi, higroskopis. 


\section{Pendahuluan}

Rute pemberian obat oral merupakan rute yang paling banyak digunakan untuk obat yang berefek secara sistemik, setidaknya $80 \%$ obat yang menghasilkan efek sistemik diberikan secara oral [1]. Salah satu bentuk sediaan padat oral adalah tablet. Tablet merupakan bentuk sediaan yang memiliki banyak keuntungan diantaranya lebih mudah untuk dikonsumsi, biaya produksi yang lebih rendah, serta stabil dalam penyimpanannya ${ }^{[2]}$.Tablet memberikan kenyamanan dan keamanan untuk pemberian zat aktif farmasi (API) dengan stabilitas fisikokimia yang baik dan memberikan dosis yang akurat dibandingkan dengan bentuk sediaan larutan [3].

Kualitas dan karakteristik suatu sediaan tablet harus memenuhi standar yang dapat diterima, mempertahankan kualitas tablet bertujuan untuk menghasilkan obat dengan jaminan efikasi, keamanan dan penampilan yang baik, dengan mengetahui sifat bahan baku, masalah yang terjadi dalam formulasi dapat diprediksi[4,29]. Higroskopisitas merupakan salah satu parameter kritis yang menentukan kualitas dan desain tablet ${ }^{[40]}$. Suatu bahan dikatakan higroskopis apabila terjadi peningkatan berat lebih dari $2 \%$ ketika ditempatkan pada $\mathrm{RH} 66 \%$ temperature ruang selama 24 jam ${ }^{[36]}$

Selama pembuatan tablet, kelembapan dapat memberikan reaksi yang tidak diinginkan, sehingga dapat menghasilkan kualitas tablet yang kurang baik. Kapasitas bahan serbuk untuk mengalir berkurang karena adanya kelembapan. Dalam kompresi tablet, kompresi serbuk dapat dilakukan di bawah tekanan tinggi hanya dalam keadaan kering. Kelembapan menyebabkan penggumpalan dan caking, dekomposisi obat, menurunkan nilai obat dan menyebabkan kerusakan pada proses tableting ${ }^{[5]}$. Penyerapan air dan efeknya pada waktu hancur tablet yang dikombinasikan dengan eksipien telah menunjukkan bahwa sifat fisik tablet dipengaruhi oleh absorpsi atau desorpsi air selama penyimpanan. Selain itu, zat aktif yang memiliki kelembapan tinggi dapat menghasilkan masalah penempelan pada dinding die saat kompresi tablet ${ }^{[2]}$. Ketika kelembapan berada di atas batas kelembapan dapat mempengaruhi stabilitas produk dan mempengaruhi proses manufakturing formulasi sediaan solid sehingga menghasilkan parameter evaluasi tablet yang kurang baik ${ }^{[35]}$

Melihat pengaruh zat aktif yang bersifat higroskopis terhadap formulasi suatu tablet, maka pada artikel ini akan dikaji mengenai upaya menjaga stabilitas tablet yang bersifat higroskopis.

\section{Metode}

Metode yang dilakukan pada review artikel ini adalah studi literatur yang diperoleh melalui situs PubMed, Google scholar dan Sciencedirect dengan menggunakan kata kunci "hygroscopic and moisture" "effect of hygroscopic api "formulation hygroscopic tablet" "stabilization hygroscopic solid". Artikel yang digunakan untuk studi literatur ini adalah artikel dengan rentang publikasi dari tahun 2005-2020. Literatur yang digunakan adalah artikel mengenai pengaruh kelembapan terhadap karakteristik tablet dan stabilisasi tablet yang mengandung zat aktif bersifat higroskopis. 
Jurnal-jurnal atau artikel penelitian yang didapat kemudian diseleksi berdasarkan keterkaitan topik melalui judul dan abstrak, bahasa yang digunakan adalah Bahasa Indonesia dan Inggris serta jurnal atau artikel penelitian berada pada rentang tahun 2005-2020. Sebanyak 40 artikel digunakan sebagai referensi penulisan dengan 17 artikel mengenai higroskopisitas dan kelembapan, 15 artikel mengenai penggunaan eksipien bersifat higroskopis 5 artikel mengenai penyalutan zat aktif bersifat higroskopis, 3 artikel mengenai pengemasan zat aktif bersifat higroskopis.

\section{Hasil dan Pembahasan}

\section{UPAYA MENJAGA STABILITAS TABLET YANG MENGANDUNG ZAT AKTIF HIGROSKOPIS}

Perlindungan kelembapan memainkan peran penting dalam stabilitas zat aktif selama pembuatan tablet[38]. Stabilitasi tablet yang sensitif terhaaldap kelembapan dapat dilakukan dengan berbagai cara seperti penggunaan eksipien, penyalutan dan pemilihan kemasan yang tepat dapat mempengaruhi kualitas tablet [18,27, 39].

\section{Penggunaan Eksipien Pada Zat Aktif Yang Bersifat Higroskopis}

Penggunaan eksipien secara luas telah di akui dapat mempertahankan stabilitas zat aktif yang sensitif terhadap kelembapan. Beberapa eksipien, dapat menarik kelembapan dan menstabilkan zat aktif yang sensitif terhadap kelembapan ${ }^{[11,14]}$. Eksipien yang memiliki kapasitas tinggi untuk mengikat kelembaban terequilibrasi lebih lambat ke tingkat yang lebih tinggi dari mobile free water dan akibatnya menunjukkan kompatibilitas kimia yang lebih besar dengan zat aktif yang sensitif terhadap kelembapan dibandingkan eksipien dengan kapasitas pengikatan air yang lebih rendah. Hal ini dapat menghasilkan situasi dimana eksipien yang bersifat higroskopis dapat menstabilkan obat yang sensitif terhadap kelembapan[27].

\section{Tabel 1. Penggunaan Eksipien Pada Zat Aktif Yang Bersifat Higroskopis}

\begin{tabular}{|l|l|l|l|l|l} 
No & Zat Aktif & $\begin{array}{l}\text { Metode } \\
\text { Pembuatan }\end{array}$ & Eksipien & Hasil & Referensi \\
\hline 1 & $\begin{array}{l}\text { Clopidogrel } \\
\text { Bisulfat }\end{array}$ & $\begin{array}{l}\text { Granulasi } \\
\text { Basah }\end{array}$ & $\begin{array}{l}\text { Menggunakan } \\
\text { aerosil sebagai } \\
\text { antiadherent } \\
\text { dan glidant }\end{array}$ & $\begin{array}{l}\text { Antiadherent } \\
\text { dan glidant } \\
\text { sebanyak 2,5\% } \\
\text { dan 0,75\% } \\
\text { mengatasi } \\
\text { penempelan } \\
\text { tablet pada } \\
\text { punch dan die }\end{array}$ & \\
& & &
\end{tabular}




\begin{tabular}{|c|c|c|c|c|}
\hline L-Karnitin & $\begin{array}{l}\text { Granulasi } \\
\text { Basah }\end{array}$ & $\begin{array}{l}\text { Menggunakan } \\
\text { Avicel PH } 101 \\
\text { dan aerosil } 200\end{array}$ & $\begin{array}{l}\text { Avicel } \mathrm{PH} 101 \\
50 \% \text { sebagai } \\
\text { pengisi, dan } \\
\text { aerosil } 200 \quad 1 \% \\
\text { sebagai } \\
\text { absorben } \\
\text { menunjukkan } \\
\text { kekerasan } \\
\text { diantara } 4-8 \mathrm{~kg} \\
\text { dan } \\
\text { friabilitas }<1 \%\end{array}$ & [12] \\
\hline $\begin{array}{l}\text { Asam } \\
\text { Askorbat }\end{array}$ & $\begin{array}{l}\text { Kempa } \\
\text { Langsung }\end{array}$ & $\begin{array}{l}\text { Menggunakan } \\
\text { Avicel PH } 102 \\
\text { dan dikalsium } \\
\text { fosfat anhidrat }\end{array}$ & $\begin{array}{l}\text { Avicel } \mathrm{PH} 102 \\
\text { ikalsium fosfat } \\
\text { anhidrat } \\
\text { menunjukkan } \\
\text { kekerasan } 4,69 \\
\mathrm{~kg} \text {, friabilitas < } \\
1 \% \text { dan waktu } \\
\text { hancur tablet } \\
44 \text { detik }\end{array}$ & [13] \\
\hline $\begin{array}{l}\text { Ekstrak } \\
\text { Valeriana } \\
\text { officinalis }\end{array}$ & $\begin{array}{l}\text { Kempa } \\
\text { Langsung }\end{array}$ & $\begin{array}{l}\text { Ekstrak } \\
\text { dikombinasikan } \\
\text { dengan aerosil } \\
\text { sebanyak } 1: 1 \\
\text { dan } \\
\text { dikeringkan } \\
\text { menggunakan } \\
\text { oven } 50^{\circ} \mathrm{C} \text {. }\end{array}$ & $\begin{array}{l}\text { Pengeringan } \\
\text { dengan aerosil } \\
\text { berpengaruh } \\
\text { baik pada daya } \\
\text { alir yaitu sudut } \\
\text { istirahat } \\
\text { menunjukkan } \\
33^{\circ}\end{array}$ & [14] \\
\hline
\end{tabular}




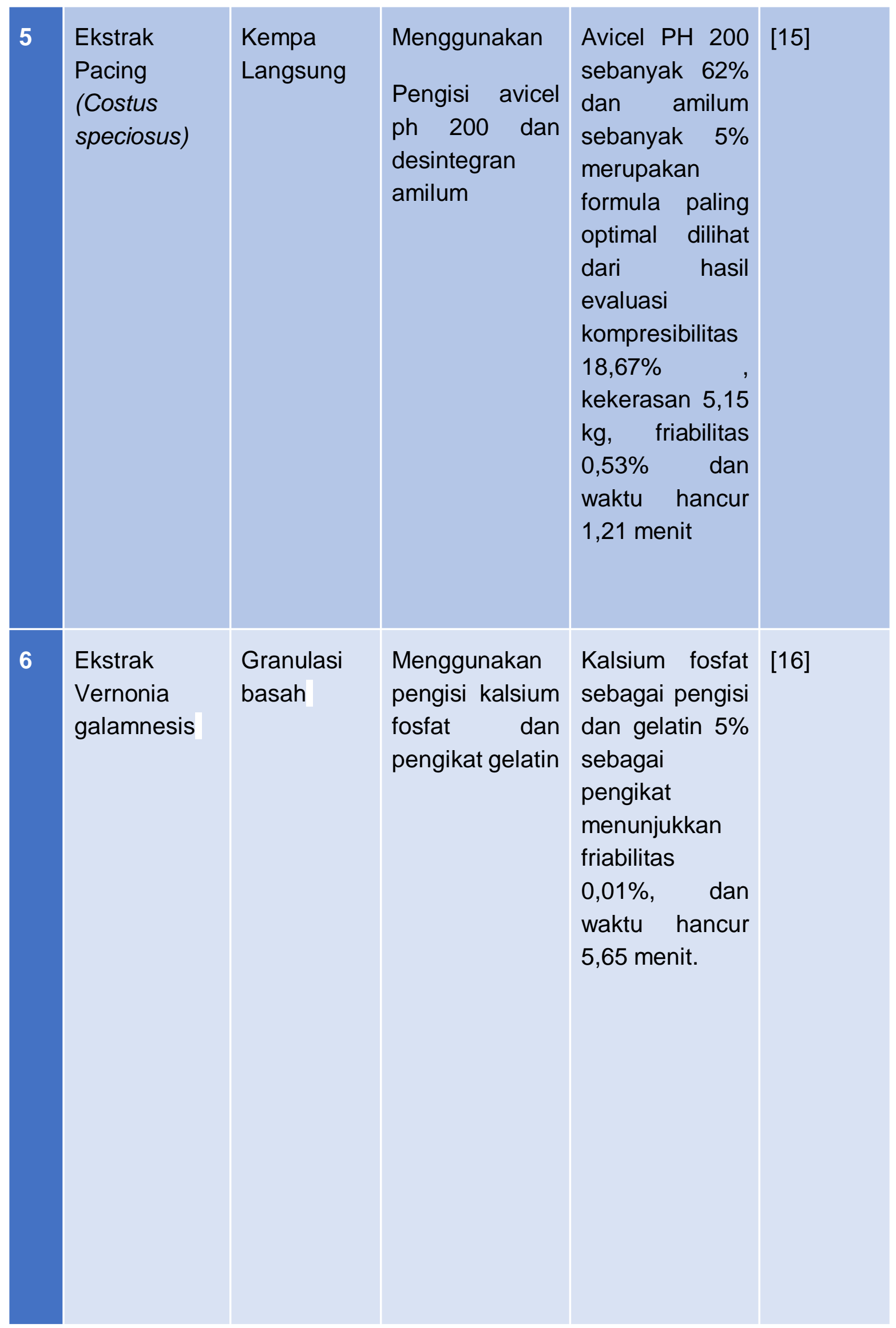




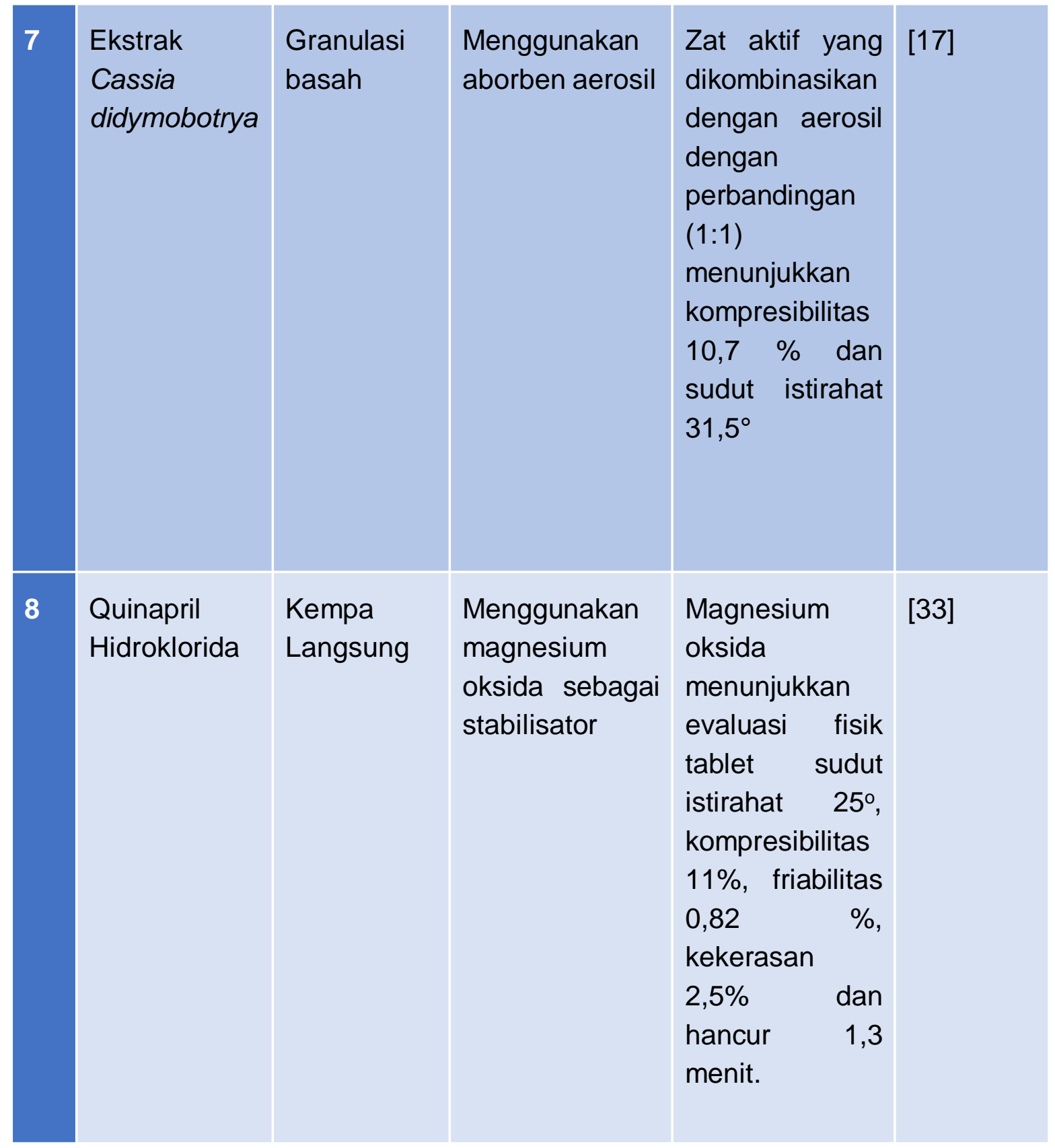

\section{Clopidogrel Bisulfat}

Clopidogrel bisulfat merupakan penghambat agregasi platelet yang bertindak dengan menghambat langsung adenosine difosfat (ADP) yang berikatan dengan reseptor P2Y12. Clopidogrel bisulfat memiliki sifat higroskopis sehingga seringkali terjadi sticking dan picking pada permukaan punch dan die alat pencetak tablet [11]. Formula tablet clopidrogel bisulfat yang mengandung aerosil sebagai antiadherent dan glidant sebanyak 2,5 dan $0,75 \%$ merupakan formula optimum untuk mencegah menempelnya serbuk pada permukaan punch dan die alat pencetak tablet. Aerosil memiliki daya alir yang baik dikarenakan distribusi ukuran partikel yang seragam dengan luas permukaan yang sangat besar. 
Aerosil menutupi partikel clopidogrel bisulfat dengan mengurangi luas permukaan clopidogrel bisulfat yang terkena paparan, sehingga menurunkan kemungkinan clopidogrel bisulfat menempel pada permukaan logam. Evaluasi menunjukkan sudut istirahat clopidgrel lebih besar dari $45^{\circ}$ menurun menjadi $40^{\circ}$ setelah dikombinasikan dengan aerosil, dengan demikian meningkatkan daya alir. Selain itu penambahan aerosil mengatasi pelengketan clopidogrel pada permukaan punch dan die ${ }^{[11]}$.

\section{L-karnitin}

L-karnitin adalah turunan asam amino non essential dan merupakan kofaktor dari metabolisme asam lemak di jantung, hati dan otot rangka ${ }^{[19]}$. L-karnitine bersifat higroskopis sehingga ketika di formulasikan menjadi tablet, terjadi masalah seperti picking/sticking pada permukaan punch dan die. Formula tablet I-karnitin yang mengandung pengisi avicel $\mathrm{PH} 101$ dapat mengurangi sticking pada punch dan die, hal ini dikarenakan avicel PH 101 juga bertindak sebagai absorben pada konsentrasi 20$90 \%[20]$. Hasil menunjukkan formulasi tablet I-karnitine yang optimum dapat dicapai menggunakan avicel $\mathrm{PH} 101$ 50\% sebagai pengisi, aerosil $2001 \%$ sebagai absorben dan magnesium stearate $2 \%$ sebagai lubrikan. Formula tersebut menghasilkan tablet Ikarnitin dengan kekerasan 4-8 kg dan friabilitas dibawah $1 \%$.

\section{Asam Askorbat}

Vitamin $\mathrm{C}$ atau asam askorbat merupakan vitamin larut air yang terdapat dalam buahbuahan dan sayuran segar [21]. Vitamin c mempunyai sifat higroskopis dan tidak tahan terhadap kelembapan ${ }^{[13]}$. Formula tablet vitamin $\mathrm{c}$ yang diformulasikan menggunakan kombinasi antara avicel PH $102 \quad 37,5 \%$ dan dikalsium fosfat anhidrat 37,5\% menunjukkan kekerasan yang baik yaitu $4,69 \mathrm{~kg}$, uji friabilitas formula yang mengandung avicel PH 102 memiliki hasil yang mendekati syarat yaitu 1\% dan memiliki waktu hancur yang baik yaitu kurang dari 15 menit. Hal ini dikarenakan avicel PH 102 memiliki sifat hidrofilik, sehingga saat kontak dengan air akan menfasilitasi masuknya air ke dalam sediaan tablet, dengan adanya air yang masuk ke dalam sediaan tablet menyebabkan bahan penghancur mengembang dan menyebabkan sediaan tablet hancur[22].

\section{Ekstrak akar valerian (Valeriana officinalis)}

Akar Valerian (Valeriana officinalis) merupakan ekstrak herbal yang banyak digunakan untuk pengobatan anxietas dan insomnia[23]. Ekstrak Valeriana officinalis memiliki afinitas uap air yang tinggi, cenderung higroskopis [14]. Formulasi Ekstrak Akar Valeriana officinalis yang bersifat higroskopis dilakukan dengan mengeringkan ekstrak terlebih dahulu dan dikombinasikan dengan aerosil. Esktrak dikeringkan menggunakan oven $50^{\circ} \mathrm{C}$ sebanyak $1: 1$. Dari hasil pengeringan, diketahui ekstrak mempunyai sifat alir yang baik sehingga dilanjutkan formulasi menggunakan metode kempa langsung. Formula yang mengandung avicel PH 101 24\% menghasilkan waktu hancur kurang dari 40 detik. Penambahan aerosil dalam ekstrak Valeriana officinalis memberikan efek antiplasticizing yang menghasilkan suhu transisi kaca hampir konstan $\left(\approx 72^{\circ} \mathrm{C}\right)^{[14]}$. 


\section{Ekstrak pacing (Costus speciosus)}

Ekstrak Pacing (Costus speciosus) adalah herba tanaman asli Indonesia. Herba ini dapat digunakan sebagai kontrasepsi pria yang efektif karena mengandung diosgenin yang mampu menghambat spermatogenesis ${ }^{[24]}$. Ekstrak pacing memiliki sifat higroskopis dan daya alir yang buruk[20]. Tanpa pengisi, tablet akan memiliki friabilitas yang buruk dan tidak dapat disimpan dalam waktu yang lama. Untuk mengatasi masalah tersebut, dibutuhkan eksipien yang dapat meningkatkan daya alir serbuk dan menutupi sifat higroskopis dari ekstrak. Pada formulasi ekstrak ini digunakan aerosil 7,4\%, magnesium stearate $7,5 \%$, manitol $25 \%$ dan avicel PH 200. Hasil menunjukkan avicel PH 200 dapat meningkatkan kekerasan tablet, semakin tinggi konsentrasi avicel PH 200 dalam tablet, semakin meningkatkan kompaktibilitas dan kekerasan tablet. Selain itu, avicel PH200 juga meningkatkan waktu hancur tablet. Jumlah optimal kombinasi avicel PH 200 dan amilum yang optimum pada ekstrak Pacing (Costus speciosus) yaitu avicel PH 200 sebanyak $62 \%$ dan amilum sebanyak $5 \%$ [15].

\section{Ekstrak Vernonia galamnesis}

Daun Vernonia galamensis telah banyak digunakan dalam pengobatan tradisional seperti mengatasi diabetes mellitus [25]. Ekstrak air daun Vernonia galamensis ditemukan sangat higroskopis ${ }^{[16]}$. Formulasi esktrak Vernonia galamnesis dilakukan dengan mengkombinasikan ekstrak dengan variasi pengisi avicel PH 101, kalsium fosfat dan aerosil 200. Selain itu digunakan gelatin sebagai pengikat dengan variasi konsentrasi $2,5 \%$, 5\% dan 7,5\%. Diketahui bahwa formula mengandung pengisi kalsium fosfat dan pengikat gelatin $5 \%$ menunjukkan hasil evaluasi fisik friabilitas $0,01 \%$, dan waktu hancur 5,65 menit ${ }^{[16]}$.

\section{Ekstrak Cassia didymobotrya}

Ekstrak Cassia didymobotrya merupakan tumbuhan yang secara tradisional digunakan untuk mengatasi konstipasi, batuk, dispesia dan bronchitis ${ }^{[26]}$. Ekstrak daun Cassia didymobotrya diformulasikan dengan menggunakan absorben aerosil. Ekstrak Cassia didymobotrya diketahui bersifat sangat higroskopis dan cenderung sticking dan menjadi cair. Untuk mengatasi masalah tersebut tablet di kombinasikan dengan aerosil dan eksipien lainnya (laktosa, mikrokristalin selulosa, sodium starch glycolate, sodium lauril sulfat, talkum dan magnesium stearat). Sebelum di granulasi, ekstrak dikombinasikan terlebih dahulu dengan aerosil dengan perbandingan 1:1. Diketahui tablet yang dihasilkan memenuhi syarat uji evaluasi fisik dan aerosil efektif digunakan sebagai absorben untuk mengatasi higroskopisitas pada ekstrak ${ }^{[17]}$.

\section{Quinapril Hidroklorida}

Quinapril hidroklorida digunakan dalam mengatasi hipertensi atau gagal jantung kongestif[32]. Formulasi tablet quinapril hidroklorida yang bersifat higroskopis dikombinasikan dengan magnesium oksida 1,92\% sebagai stabilisator menunjukkan hasil evaluasi fisik tablet yang baik yaitu sudut istirahat sebesar $25^{\circ}$, kompresibilitas $11 \%$, friabilitas $0,82 \%$, kekerasan $2,5 \%$ dan waktu hancur 1,3 menit ${ }^{[33]}$. 


\section{PENYALUTAN TABLET PADA ZAT AKTIF YANG BERSIFAT HIGROSKOPIS}

Bentuk sediaan padat farmasi dengan penyalutan adalah prosedur yang digunakan untuk berbagai tujuan seperti estetika, menutupi bau dan perlindungan dari kondisi lingkungan seperti kelembapan ${ }^{[27]}$. Bentuk sediaan akhir obat dengan penyalutan yang tepat memungkinkan untuk melindungi zat aktif yang bersifat sensitif terhadap kelembapan. Bahan penyalut yang bersifat hidrofobik di alam dapat untuk mencegah masuknya uap air ke dalam sistem dari lingkungan sekitarnya ${ }^{[4]}$.

\section{Ranitidin $\mathrm{HCl}$}

Ranitidin $\mathrm{HCl}$ merupakan senyawa higroskopis yang mengabsorpsi kelembapan dari lingkungan ${ }^{[18]}$. Ranitidine $\mathrm{HCl}$ adalah antagonis reseptor $\mathrm{H} 2$ histamin, yang digunakan dalam pengobatan ulkus duodenum dan ulkus lambung [28]. Ranitidin $\mathrm{HCl}$ yang disalut menggunakan hydroxypropyl methyl cellulose (HPMC) didispersikan dalam etanol (96\%) dan campuran metilen klorida menunjukkan evaluasi penyerapan jumlah air yang baik. Bentuk sediaan tablet yang tidak disalut menyerap jumlah air maksimum yaitu 4,5\% sementara tablet yang dilakukan penyalutan menyerap paling sedikit kelembapan yaitu $2 \%{ }^{[18]}$.

\section{Cabergolin}

Cabergolin merupakan zat aktif yang memiliki stabilitas yang buruk, dan sangat sensitif terhadap lembap. Tablet dilakukan penyalutan menggunakan hydroxypropyl methyl cellulose (HPMC) 4,9\%, titanium oksida 0,4 \%, hipromellosa 2,1\%, PEG 4000 0,4\%, metilen klorida $4,9 \%$ dan etanol. Hasil uji stabilitas dipercepat menunjukkan bentuk sediaan tablet yang tidak disalut menyerap jumlah air maksimum yaitu $4,5 \%$ sementara tablet yang tidak disalut menyerap kelembapan $2 \% \cdot{ }^{[34]}$.

\section{PENGGUNAAN KEMASAN TABLET PADA ZAT AKTIF YANG BERSIFAT HIGROSKOPIS}

Pengemasan adalah suatu metode untuk melindungi produk farmasi terhadap pengaruh luar. Kemasan dari obat-obatan biasanya memberikan regulasi, keamanan, identitas, kenyamanan penanganan dan kemudahan pengiriman. Faktor eksternal yang dapat mengurangi kualitas atau potensi produk farmasi adalah cahaya, kelembapan, oksigen, kontaminasi dan kerusakan mekanis ${ }^{[5]}$. Kemasan primer yang digunakan pada sediaan tablet harus inert dan tidak berinteraksi dengan zat aktif contohnya adalah blister dan strip. Selain itu kemasan harus melindungi sifat fisik, aman terhadap kerusakan dan dapat melindungi identitas produk terhadap partikel kimia, biologis atau fisik[5].

\section{Ranitidin $\mathrm{HCl}$}

Pengemasan tablet ranitidin $\mathrm{HCl}$ yang bersifat sensitif terhadap kelembapan membandingkan kemasan pvc-alu foil dan alu-alu foil. Kemudian dilakukan studi jumlah kelembapan yang diserap. 
Hasil evaluasi penyimpanan hingga hari ke 60 kelembapan yang diserap oleh ranitidin $\mathrm{HCl}$ yang dikemas oleh pvc-alu foil yaitu sebanyak 35\% sedangkan tablet yang dikemas menggunakan alu-alu foil kurang dari $5 \%$. Tablet yang dikemas menggunakan pvc-alu foil menjadi lebih lembap dan berubah warna. Sedangkan tablet yang dikemas menggunakan alu-alu foil tidak terlihat perubahan warna dan mengabsorbsi sedikit lembap ${ }^{[18]}$.

\section{Cabergolin}

Pengemasan tablet ranitidin $\mathrm{HCl}$ yang bersifat sensitif terhadap kelembapan membandingkan pengemasan menggunakan aluminum dan polyvinilidyn chloride, Kemudian dilakukan studi jumlah kelembapan yang diserap. Tablet cabergolin yang dikemas menggunakan polyvinilidyn chloride menunjukkan kekerasan yang menurun dibandingkan dengan tablet yang dikemas menggunakan alumunium yang mempertahankan kekerasannya [15].

\section{SIMPULAN}

Review ini membahas pengaruh higroskopisitas terhadap karakteristik fisika tablet dan upaya dalam mengatasi higroskopisitas tersebut melalui pemilihan eksipien, penyalutan dan pemilihan kemasan yang tepat. Penggunaan aerosil sebagai absorben pada berbagai zat aktif higroksopis dengan konsentrasi $0,75-7 \%$ dan penggunaan avicel sebagai pengisi dengan konsentrasi $24-62 \%$ menghasilkan kualitas tablet yang baik. Penyalutan menggunakan hydroxypropylmethyl cellulose (HPMC) yang didispersikan dalam etanol dan campuran metilen klorida dapat mengurangi penyerapan kelembapan pada tablet ranitidin $\mathrm{HCl}$ dan cabergoline. Penggunaan kemasan PVC-Alu foil efektif dalam melindungi zat aktif yang bersifat higroskopis dari pengaruh kelembapan. Selain itu, penggunaan kemasan alumunium menunjukkan kekerasan yang lebih baik pada uji stabilitas dibandingkan dengan tablet yang dikemas menggunakan PVDC. 


\section{Daftar Pustaka}

1. Bibi, R., Naqvi, B.S., Shoaib, M.H. and Rahim, N. Design and evaluation of a new formulation of enalapril maleate tablet. Pak J Pharm Sci. 2011. 24, pp.211215.

2. Pawar R, Jaimini M, Chauhan BS, Sharma SK. Compression coated tablets as drug delivery system (tablet in tablet): a review. International Journal of Pharmaceutical Research and Development. 2014 Mar;6(1):21-33.

3. Gaikwad VD, Yadav VD, Gaikwad MD. Novel sustained release and swellable gastroretentive dosage form for ciprofloxacin hydrochloride. International journal of pharmaceutical investigation. 2014 Apr;4(2):88-92.

4. Jin P, Madieh S, Augsburger LL. Selected physical and chemical properties of feverfew (Tanacetum parthenium) extracts important for formulated product quality and performance. AAPS PharmSciTech. 2008 Mar 1;9(1):22-30.

5. Anbarasan A, Nataraj J, Shanmukhan N, Radhakrishnan A. Effect of hygroscopicity on pharmaceutical ingredients, methods to determine and overcome: an overview. Journal of Chemical and Pharmaceutical Research. 2018;10(3):61-7.

6. Dely A, Lodin U, Nangia A, inventors; Andrx Labs LLC, assignee. Formulations including hygroscopic compounds. United States patent application US 11/391,739. 2007 Oct 4.

7. Singh S. Increase In The Rate Of Moisture Gain By Hygroscopic Drugs In The Presence Of Non-Hygroscopic Water-Soluble Substances: Study Of The Generalization Of This Hitherto Unknown Phenomenon, Explanation To Its Occurrence And Implications In Formulation Developm. Asian Journal Of Pharmaceutics (Ajp): Free Full Text Articles From Asian J Pharm. 2016 Sep 9;1(1):69-76

8. Roy S, et al. A systemic approach on understanding the role of moisture in pharmaceutical product degradation and its prevention: challenges and perspectives. Biomedical Research 2018; 29 (17): 3336-3343

9. Nokhodchi A, Javadzadeh $\mathrm{Y}$. The effect of storage conditions on the physical stability of tablets. Pharmaceutical Technology Europe. 2007 Jan 1;19(1):20.

10. Tomar M, Kumar SA, Raj SA. Effect of moisture content of exicipient (microcrystalline cellulose) on direct compressible solid dosage forms. International Journal of Pharmaceutical Sciences and Research. 2017;8(1):282.

11. Lei J, Sha P, Jin R, Shi Y, Shen X, inventors; Shanghai Anbison Laboratory Co., Ltd., assignee. Preparation method of the solid formulation of Clopidogrel bisulfate. United States patent US 9,144,550. 2015 Sep 29.

12. Badawi AA, Hegazy MM, Louis D, Eldegwy MA. Solving manufacturing problems for L-carnitine-L-tartrate to improve the likelihood of successful product scale-up. Acta Pharmaceutica. 2017 Dec 20;67(4):511-25.

13. Riyanti, K.M.P. and Rohmani, S., Pengaruh Variasi Konsentrasi Avicel PH 102 dengan Dikalsium Fosfat Anhidrat sebagai Fillerbinder terhadap Sifat Fisik Tablet Vitamin C. In Prosiding APC (Annual Pharmacy Conference) (Vol. 3, No. 1). 
14. Gallo L, Ramírez-Rigo MV, Piña J, Palma S, Allemandi D, BucalÁ V. Valeriana officinalis dry plant extract for direct compression: preparation and characterization. Scientia pharmaceutica. 2012 Dec;80(4):1013-26.

15. Damayanti D, Sari IP, Sulaiman TS, Bestari AN, Setiawan IM. The Formulation of Pacing (Costus speciosus) Extract Tablet by Using Avicel® Ph 200 As FillerBinder and Amylum As Disintegration Agent. Indonesian Journal of Pharmacy. 2018 Jan 2;29(1):29.

16. Autamashih $M$, Isah $A B$, Allagh TS, Ibrahim MA. Use of avicel® ph-103 and selected binders in the tablet formulation of the del-iquescent crude leaves extract of Vernonia galamensis (Asteraceae). International Journal of Research in Pharmaceutical Sciences. 2011 Apr 25;2(2):295-300.

17. Wendemagegn Sm. Formulation Of Cassia Didymobotrya Leaf Laxative Tablets (Doctoral Dissertation, University Of Nairobi). 2016

18. Islam SA, Hossain MA, Kabir AH, Kabir S, Hossain MK. Study of moisture absorption by ranitidine hydrochloride: effect of\% $\mathrm{RH}$, excipients, dosage forms and packing materials. Dhaka University Journal of Pharmaceutical Sciences. 2008;7(1):59-64.

19. Nishimura $M$, et al. Effects of intravenous L-carnitine on myocardial fatty acid imaging in hemodialysis patients: responders or non-responders to L-carnitine. SpringerPlus. 2015 Dec 1;4(1):353.

20. Guy A. Cellulose, Microcrystalline, dalam Rowe, R.C., Sheskey, P.J., dan Quinn, M.E., (Eds.), Handbook of Pharmaceutical Excipients, 6 th Ed., 129-131, London: Pharmaceutical Press;2009

21. Rahman MS, Al-Rizeiqi MH, Guizani N, Al-Ruzaiqi MS, Al-Aamri AH, Zainab S. Stability of vitamin $\mathrm{C}$ in fresh and freeze-dried capsicum stored at different temperatures. Journal of food science and technology. 2015 Mar 1;52(3):1691-7.

22. Hadisoewignyo L, Teny Gracesya Florensya, dkk Pengaruh bahan pengisi padat Ibu Profen dengan metode cetak langsung, Majalah farmasi Indonesia (22). 2011; hal. 279-285.

23. Tong HH, Wong SY, Law MW, Chu KK, Chow AH. Anti-hygroscopic effect of dextrans in herbal formulations. International journal of pharmaceutics. $2008 \mathrm{Nov}$ 3;363(1-2):99-105.

24. Sari IP, Nurrochmad A, Rahayu S. Evaluation of Anti-Fertility Effect of Aqueous Extract of Costus speciosus (Koen.) JE Smith Rhizome in Mice. Int J Pharm Chem Res. 2016;8:440-.

25. Allagh TS, Ameh GO, Okafor IS. Formulation and evaluation of the physicochemical properties of Ageratum conyzoides (Fam asteraceae) granules and tablets. Niger J Pharm Sci. 2009 Oct;8:18-25.

26. Choudhari Y, Hoefer H, Libanati C, Monsuur F, McCarthy W. Mesoporous silica drug delivery systems. InAmorphous Solid Dispersions 2014 (pp. 665-693). Springer, New York, NY.

27. Rajabi-Siahboomi AR, Levina M, Upadhye SB, Teckoe J. Excipient Selection in Oral Solid Dosage Formulations Containing Moisture Sensitive Drugs. InExcipient Applications in Formulation Design and Drug Delivery 2015 (pp. 385421). Springer, Cham. 
28. Pahwa R, Sharma S, Kumar V, Kohli K. Ranitidine hydrochloride: An update on analytical, clinical and pharmacological aspects. J Chem Pharm Res. 2016;8(7):70-80.

29. Silverstein: Excipient quality and selectionPharmaceutical technology Europe 2016; 28 (2): 16-20.

30. Waterman, K.C.,Adami, R.C..Accelerated aging: prediction Of chemical stability of pharmaceuticals. Int.J.Pharm. 2016; 293 (1-2): 101-125.

31. Hockerfelt, M.H., Alderborn, G.,. The crystallinity of cellulose controls The physical distribution of sorbed water and the capacity to present water for chemical degradation of a solid drug. Int.J. Pharm. 2014;477 (1-2): 326-333.

32. Accupril (Quinapril Hydrochloride) Product Monograph. Canada: Parke Davis and Company Pfizer Inc. [di unduh 30 Juni 2020] Tersedia dari: https://www.pfizer.ca/sites/default/files/201710/accupril_pm_200979_e_14mar20 17_clean.pdf.

33. Shwetha margret jl, \& madhavi blr. Study of direct compression method for the preparation of quinapril hydrochloride tablets. Asian journal of pharmaceutical and clinical research. 2019; 13 (1): 202-211.

34. Alsabbagh, M., Abdel, W., Khalyl, A. Assesment of the Impact of Formulation and Packaging on the Stability of Cabergoline Tablets. International Journal of Pharmacy and Pharmaceutical Science. 2012; 4 (5), 511-518

35. Monika Tomar, Ajay Kumar Singh and Amit Raj Sinha. Physicochemical parameter of microcrystalline cellulose and the most acceptability in pharmaceutical Industries. Journal of Innovations in Pharaceuticals and biological Sciences. 2015; 2(4):570-578.

36. Richardson, P.H., Balchem Corp. Stable hygroscopic compositions and methods for stabilizing hygroscopic ingredients. U.S. Patent. 2006; 6: 797, 291

37. Akhavan-Mahdavi, S., S. M. Jafari, E. Assadpoor and D. Dehnad. Microencapsulation optimization of natural anthocyanins with maltodextrin, gum Arabic and gelatin. Int. J. Biol. Macromol. 2016; 85: 379-385

38. Joshi, S. and Petereit, H.U. Film coatings for taste masking and moisture protection. International journal of pharmaceutics. 2013; 457(2): 395-406.

39. Snyder, H.E dan Lechuga-Ballesteros, D. Spray drying: theory and Pharmaceutical applications. In: Pharmaceutical Dosage Forms: (Tablets L.L. Augsburger and S.W. Hoag). New York: Informa Health Care; 2008

40. Thoorens G, Krier F, Leclercq B, Carlin B, Evrard B. Microcrystalline cellulose, a direct compression binder in a quality by design environment.. Int $\mathrm{J}$ Pharm. 2015; 473(1-2):64-72. 